NASZA DERMATOLOGIA Online OUR DERMATOLOGY Online

Source of Support:

Nil

Competing Interests:

None

\section{A MINI-REVIEW ON EPONYMS IN THE DERMATOLOGY LITERATURE LINKED TO FRANCE}

\author{
Ahmad Al Aboud ${ }^{1}$, Khalid Al Aboud ${ }^{2}$ \\ ${ }^{1}$ Dermatology Department, King Abdullah Medical City, Makkah, Saudi Arabia \\ ${ }^{2}$ Department of Public Health, King Faisal Hospital, Makkah, Saudi Arabia
}

Corresponding author: Dr. Khalid Al Aboud

amoa65@hotmail.com
France officially the French Republic France is the largest country in Western Europe and the third-largest in Europe as a whole [1]. It possesses the second-largest exclusive economic zone in the world.

It has been a major power with strong cultural, economic, military, and political influence in Europe and around the world. Its estimated current population is around $65,350,000$

The French healthcare system was ranked first worldwide by the World Health Organization in 1997 and then again in 2000. Care is generally free for people affected by chronic diseases [1]. Many eponyms we use them currently, in our dermatology practice, originated from France. For example, Schnitzler's syndrome which is characterized by recurrent urticarial rash and monoclonal gammopathy is named after the French dermatologist L. Schnitzler (Fig. 1) who first described this syndrome in 1972. As a matter of fact one my need to write a book if he or she wish to discuss French dermatological eponyms in details.

However, in this communication, we meant to shed some lights only, on some examples of French dermatological eponyms, which we summarized it in Table I [2-20].

\begin{tabular}{|c|l|}
\hline $\begin{array}{c}\text { Eponyms in the dermatology } \\
\text { literature linked to France }\end{array}$ & \multicolumn{1}{c|}{ Remarks } \\
\hline $\begin{array}{c}\text { Acrodermatitis continua of } \\
\text { Hallopeau [2] }\end{array}$ & $\begin{array}{l}\text { It an uncommon variant of pustular psoriasis first described by Hallopeau in 1890. François } \\
\text { Henri Hallopeau (1842-1919), (Fig. 2), was a French dermatologist Other condition named } \\
\text { after him is Recessive dystrophic epidermolysis bullosa (also known as ,Hallopeau-Siemens } \\
\text { variant of epidermolysis bullosa"). Hermann Werner Siemens (1891-1969) was a German } \\
\text { dermatologist. }\end{array}$ \\
\hline $\begin{array}{c}\text { Confluent and reticulated } \\
\text { papillomatosis of Gougerot and } \\
\text { Carteaud [3] }\end{array}$ & $\begin{array}{l}\text { Also known as Confluent and reticulated papillomatosis. Named for, 2 French physicians; Henri } \\
\text { Gougerot (1881-1955), (Fig. 3), and Alexandre Carteaud (born 1897), Who originally described } \\
\text { the condition in 1927. }\end{array}$ \\
\hline
\end{tabular}

Table I. Selected Eponyms in the dermatology literature linked to France

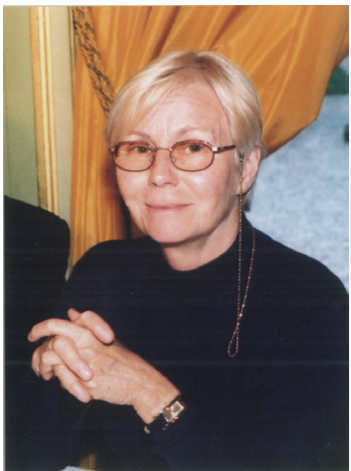

Figure 1. Picture of Liliane Schnitzler who was the first women to be made a Professor in dermatology, in France, and head of department at the age of 31 .

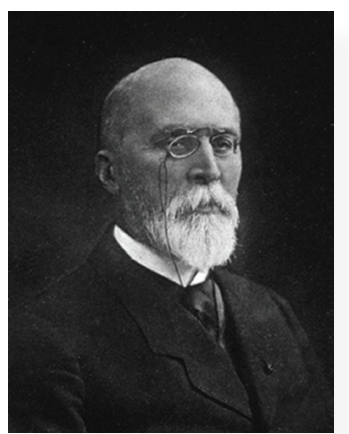

Figure 2. François Henri Hallopeau (1842-1919)

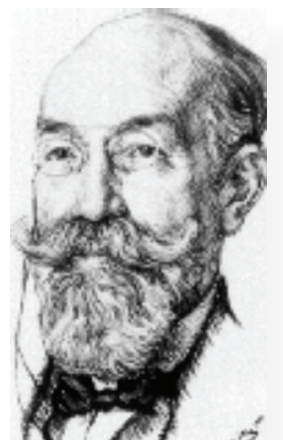

Figure 3. Henri Gougerot (1881-1955) 


\begin{tabular}{|c|c|}
\hline $\begin{array}{l}\text { Eponyms in the dermatology } \\
\text { literature linked to France }\end{array}$ & Remarks \\
\hline Darier disease [4] & $\begin{array}{l}\text { Also known as Darier disease, Darier-White disease, Dyskeratosis follicularis and Keratosis } \\
\text { follicularis. It is an autosomal dominant disorder discovered by Ferdinand-Jean Darier ( } 856- \\
\text { 1938), (Fig. 4), who was a French physician, pathologist and dermatologist called the „father of } \\
\text { modern dermatology in France”. }\end{array}$ \\
\hline Degos disease [5] & $\begin{array}{l}\text { Robert Degos (1904-1987), (Fig. 5), was a French dermatologist who described several } \\
\text { dermatoses including Degos disease (also called malignant atrophic papulosis) which is an } \\
\text { extremely rare vasculopathy which results in tissue infarction. }\end{array}$ \\
\hline Erythema induratum of Bazin [6] & $\begin{array}{l}\text { In 1861, Bazin gave the name erythema induratum to a nodular eruption that occurred on the } \\
\text { lower legs of young women with tuberculosis. Erythema induratum/nodular vasculitis complex } \\
\text { is classified into } 2 \text { variants: erythema induratum of Bazin type and nodular vasculitis or erythema } \\
\text { induratum of Whitfield type. The Bazin type is related with tuberculous origin, but Whitfield type } \\
\text { is not. Ernest Bazin (1894-1964), (Fig. 6), was a French physician. }\end{array}$ \\
\hline Favre-Racouchot syndrome [7] & $\begin{array}{l}\text { It is a disorder consisting of multiple open and closed comedones in the presence of actinically } \\
\text { damaged skin. It is named after the French dermatologist Maurice Favre (1876-1954) and his } \\
\text { pupil Jean Racouchot (1908-1994). }\end{array}$ \\
\hline Fournier's gangrene [8] & $\begin{array}{l}\text { Fulminating infection of the scrotum leading to gangrene and commonly associated with } \\
\text { diabetes. It is a type of necrotizing infection or gangrene usually affecting the perineum. It was } \\
\text { first described by Baurienne in } 1764 \text { and is named after, Jean Alfred Fournier (1832-1914), } \\
\text { French dermatologist (Fig. 7). }\end{array}$ \\
\hline Griscelli syndrome (GS) [9] & $\begin{array}{l}\text { It is a rare autosomal recessive disorder characterized by albinism (hypopigmentation) with } \\
\text { immunodeficiency, that usually causes death by early childhood. It is caused by mutations } \\
\text { in either the myosin VA (GS1), RAB27A (GS2) or melanophilin (GS3) genes. The three GS } \\
\text { subtypes are commonly characterized by pigment dilution of the skin and hair, due to defects } \\
\text { involving melanosome transport in melanocytes. It is named after Claude Griscelli, (Fig. 8), born } \\
\text { in 1936, professor of pediatry at Hôpital des Enfants-Malades in Paris. }\end{array}$ \\
\hline Huriez syndrome [10] & $\begin{array}{l}\text { Palmoplantar keratoderma with scleroatrophy. Named for French dermatologist, Claude Huriez } \\
\text { (1907-1984), (Fig. 9). In 1960s, Huriez and his colleagues reported } 2 \text { families from northern } \\
\text { France with, this syndrome, which is characterized by scleroatrophy of the hands and feet, nail } \\
\text { hypoplasia, mild palmoplantar keratoderma and hypohidrosis. }\end{array}$ \\
\hline Jacquet dermatitis [11] & $\begin{array}{l}\text { It is another name for erosive form of irritant napkin dermatitis. The first true description of } \\
\text { diaper dermatitis was made by Jacquet in } 1905 .\end{array}$ \\
\hline $\begin{array}{c}\text { Laugier-Hunziker syndrome (LHS) } \\
{[12]}\end{array}$ & $\begin{array}{l}\text { LHS is a rare acquired disorder characterized by diffuse macular hyperpigmentation ofthe oral } \\
\text { mucosa and, at times, longitudinal melanonychia. Laugier-Hunziker syndromewas first described } \\
\text { in } 1970 \text { by Laugier (from France) and Hunziker (from Switzerland). }\end{array}$ \\
\hline
\end{tabular}

Table I. Selected Eponyms in the dermatology literature linked to France (continued)

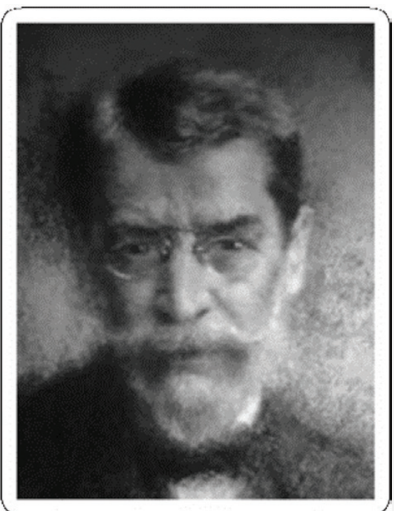

Figure 4. Ferdinand-Jean Darier (1856-1938)

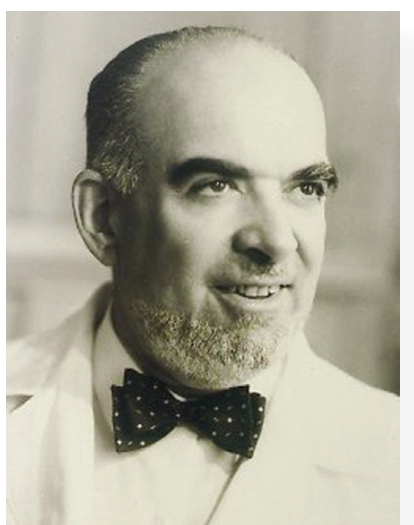

Figure 5. Robert Degos (1904-1987)

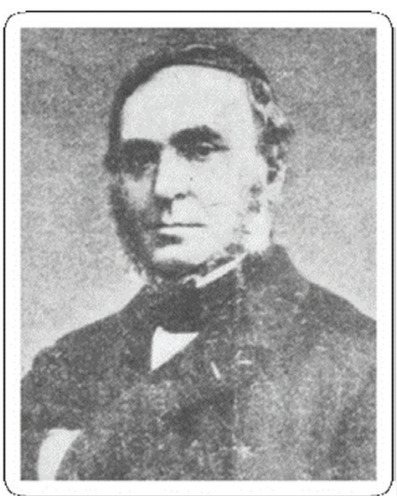

Figure 6. Ernest Bazin (1894-1964) 


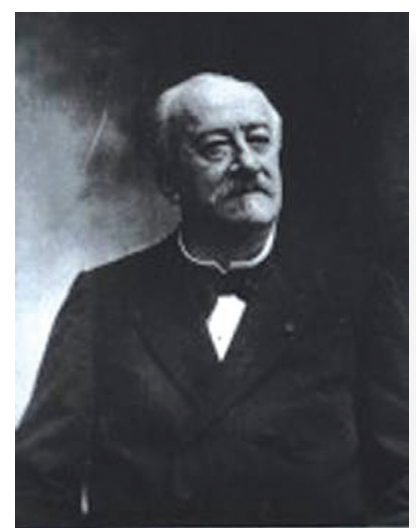

Figure 7. Jean Alfred Fournier (1832-1914)

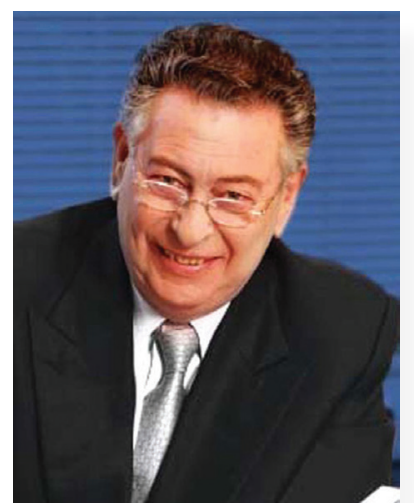

Figure 8. Professor Claude Griscelli

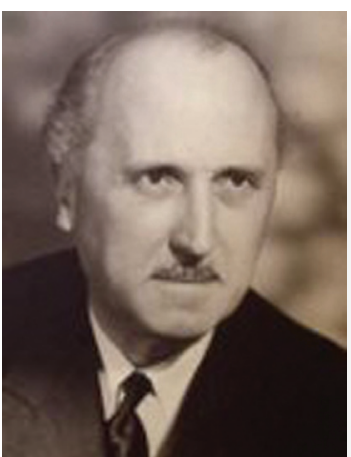

Figure 9. Claude Huriez (1907-1984)

\begin{tabular}{|c|c|}
\hline $\begin{array}{l}\text { Eponyms in the dermatology } \\
\text { literature linked to France }\end{array}$ & Remarks \\
\hline Papillon - Lefèvre syndrome [10] & $\begin{array}{l}\text { An autosomal recessive disorder characterized by diffuse, transgredient PPK in association with } \\
\text { destructive periodontitis (beginning in childhood) and premature loss of teeth. It is named for } 2 \\
\text { French dermatologists. Papillon and Paul Lefèvre, who described it in } 1924 \text {. }\end{array}$ \\
\hline Pautrier microabscess [13] & $\begin{array}{l}\text { An intraepidermal collections of malignant lymphocytes, seen in cutaneous cell lymphoma. It } \\
\text { is named after Lucien-Marie Pautrier, although he did not first describe them. Lucien-Marie } \\
\text { Pautrier (1876-1959), (Fig. 10), was a French dermatologist, who headed a leading department at } \\
\text { the medical school of Strasbourg. }\end{array}$ \\
\hline $\begin{array}{l}\text { Pigmented purpuric lichenoid } \\
\text { dermatitis of Gougerot-Blum [14] }\end{array}$ & $\begin{array}{l}\text { It is a type of pigmented purpura. It was characterized in } 1925 \text { by } 2 \text { French dermatologists; Paul } \\
\text { Blum (1878-1933) and Henri Gougerot (1881-1955). }\end{array}$ \\
\hline Poikiloderma of Civatte $[15,16]$ & $\begin{array}{l}\text { It refers to erythema associated with a mottled pigmentation seen on the sides of the neck more } \\
\text { commonly in women. Civatte first described the condition in 1923. Achille Civatte } \\
(1877-1956) \text {, (Fig. 11), was a French physician. }\end{array}$ \\
\hline Sabouraud agar $[17,18]$ & $\begin{array}{l}\text { It is a type of agar containing peptones. It is used to cultivate dermatophytes and other types of } \\
\text { fungi. It was created by, and is named after, Raymond Sabouraud in } 1892 \text {. Raymond Sabouraud } \\
\text { (1864-1938), (Fig. 12), was a French physician born in Nantes. He specialized in dermatology } \\
\text { and mycology, and was also an accomplished painter and sculptor. }\end{array}$ \\
\hline Sézary syndrome [13] & $\begin{array}{l}\text { In a series of papers from } 1938 \text { to } 1949 \text {, Albert Sézary (1880-1956), (Fig. 13), a French } \\
\text { dermatologist and syphilologist, described erythroderma with cellules monstrueuses (monster } \\
\text { cells) in the skin and blood, which is now known as Sézary syndrome or Sézary disease. }\end{array}$ \\
\hline Tzanck test $[19,20]$ & $\begin{array}{l}\text { In dermatopathology, the Tzanck test, also Tzanck smear, is scraping of an ulcer base to look for } \\
\text { Tzanck cells. It is sometimes also called the Chickenpox skin test and the herpes skin test. It is } \\
\text { named after Arnault Tzanck (1886-1954), (Fig. 14), a French dermatologist. }\end{array}$ \\
\hline
\end{tabular}

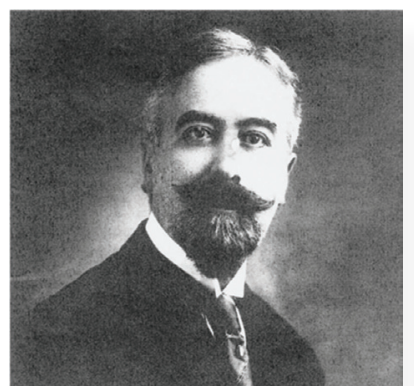

Figure 10. Lucien-Marie Pautrier (1876-1959)

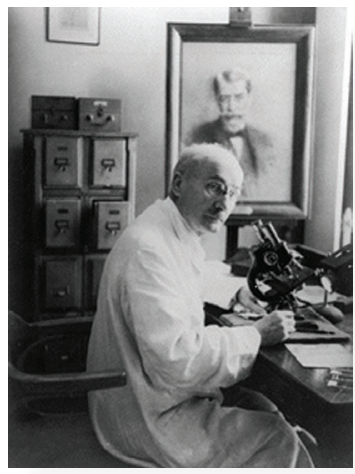

Figure 11. Achille Civatte (1877-1956)

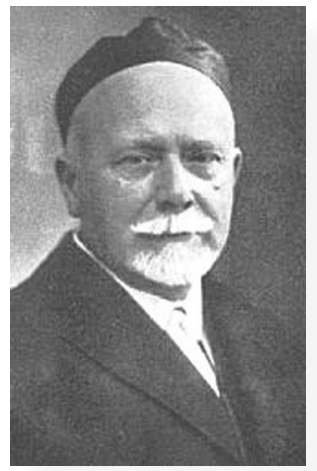

Figure 12. Raymond Sabouraud (1864-1938) 


\begin{tabular}{|c|l|}
\hline $\begin{array}{c}\text { Eponyms in the dermatology } \\
\text { literature linked to France }\end{array}$ & \multicolumn{1}{|c|}{ Remarks } \\
\hline Woringer-Kolopp disease [13] & $\begin{array}{l}\text { Pagetoid reticulosis (PR) is a rare form of cutaneous T-cell lymphoma. Two variants of } \\
\text { the disease are described: the localized type Woringer-Kolopp disease (WKD) and the } \\
\text { disseminatedtype Ketron-Goodmandisease(KGD). KGDisnamedafterLloyd W. Ketron and M.H. } \\
\text { Goodman.The term PR has been introduced by Braun-Falco et al. in 1973 to identify this clinical } \\
\text { entity, first described by Woringer and Kolopp in 1939, for the resemblance of infiltrating cells } \\
\text { characterizing this condition with Paget's cells present in the epidermotropic infiltrate of } \\
\text { mammary Paget's disease. } \\
\text { Pierre Kolopp was French physician and Frederic Woringer (1903-1964), (Fig. 15), was one of } \\
\text { Pautrier's students, who had been in charge of the Laboratoire d'Histopathologie Cutanée in } \\
\text { Strasbourg from 1930 until his death. }\end{array}$ \\
\hline
\end{tabular}

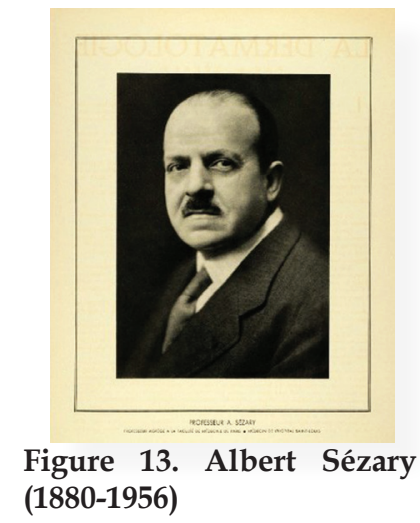

(1880-1956)

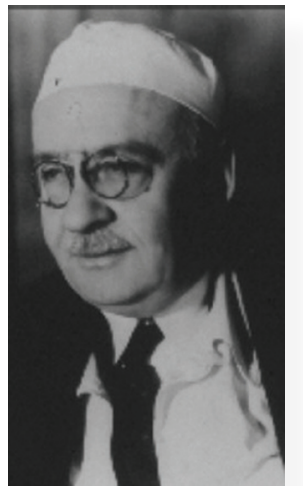

Figure 14. Arnault Tzanck (1886-1954)

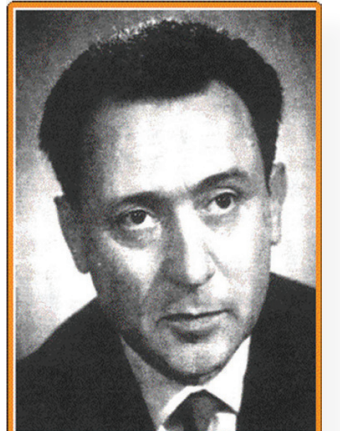

Figure 15. Frederic Woringer (1903-1964)

\section{Acknowledgment}

The authors wish to express sincere thanks to Daniel $\mathrm{R}$ Wallach, MD, Department of Dermatology of the NB Hôpital Tarnier in Paris, France, and Pascale Barre; responsible for Dermaweb, Laboratoires Pierre Fabre, for their assistance in obtaining Figure 1 in this manuscript.

\section{REFERENCES}

1. France. Wikipedia ${ }^{\circledR}$ [Internet]. Wikimedia Foundation. [Updated2 May 2013; cited 2 May 2013]. Available from: http://en.wikipedia. org/wiki/France

2. Tilles G, Wallach D: [François Henri Hallopeau (1842-1919)]. Ann Dermatol Venereol. 2001;128:1379.

3. [No authors listed]: [Tribute to Professor Henri Gougerot]. Ann Dermatol Syphiligr. 1952;79:377.

4. Ségal A: [Ferdinand-Jean Darier (1856-1938) dermatologist of world renown]. Hist Sci Med. 2009;43:389-94.

5. Saurat JH: In memoriam Professor Robert Degos (1904-1987). Dermatologica. 1987;175:265-6.

6. Vena GA, Apruzzi D, Vestita M, Panaro M, Carpagnano S, Filannino R, et al: Recurrence of erythema induratum of Bazin in a patient under chemotherapy for breast cancer. New Microbiol. 2011;34:331-3.

7.Zhang R, Zhu W: Favre-Racouchot syndrome associated with eyelid papilloma: a case report. J Biomed Res. 2012;26:474-7.

8. Al Aboud K, Al Aboud A: Eponyms in dermatology literature linked to genital skin disorders. Our Dermatol Online. 2013;4:243-6. 9. Van Gele M, Dynoodt P, Lambert J: Griscelli syndrome: a model system to study vesicular trafficking. Pigment Cell Melanoma Res.
2009;22:268-82.

10. Al Aboud K, Al Aboud A: Eponyms in the dermatology literature linked to Palmo-Plantar Keratoderma. Our Dermatol Online. 2013;4:in press.

11. Paradisi A, Capizzi R, Ghitti F, Lanza-Silveri S, Rendeli C, Guerriero C: Jacquet erosive diaper dermatitis: a therapeutic challenge. Clin Exp Dermatol. 2009;34:385-6.

12. Al Aboud K, Al Aboud D: Eponyms in dermatology literature linked to Switzerland. Our Dermatol Online. 2013; 4:121-7.

13. Al Aboud K, Al Aboud D: Eponyms in the literature of cutaneous lymphomas. Our Dermatol Online. 2013;4:385-8.

14. Lata Sharma, S. Gupta: Clinicoepidemiological study of pigmented purpuric dermatoses Indian Dermatol Online J. 2012; 3:17-20.

15. Touraine A: Achille Civatte, 1877-1956. Aust J Dermatol. 1956;3:213-4.

16. Scattone L, de Avelar Alchorne MM, Michalany N, Miot HA, Higashi VS: Histopathologic changes induced by intense pulsed light in the treatment of poikiloderma of Civatte. Dermatol Surg. 2012;38:1010-6.

17. Negroni R: Historical aspects of dermatomycoses. Clin Dermatol. 2010;28:125-32.

18. [No authors listed]: Raymond Sabouraud (1864-1938) French dermatologist. JAMA. 1970;214:363-4.

19. Vena GA, Apruzzi D, Vestita M, Panaro M, Carpagnano S, Filannino R, et al: Recurrence of erythema induratum of Bazin in a patient under chemotherapy for breast cancer. New Microbiol. 2011;34:331-3.

20. Cordero AA: The man behind the eponym. Arnault Tzanck, his work and times. Am J Dermatopathol. 1985;7:121-3. 